\title{
Studies in the Physiology of Parasitism.'
}

\author{
II. Infection by Botrytis cinerea.
}

BY

V. H. BLACKMAN, SC.D., F.R.S.,

AND

E. J. WELSFORD, F.L.S.,

From the Department of Plant Physiology and Pathology, Imperial College of Science and Technology, London.

\section{With Plate $\mathbf{X}$ and two Figures in the Text.}

$T$

HE germ tubes of parasitic fungi which are not wound parasites usually infect the aerial parts of plants by entering through the stomata or by boring through the outer walls of the epidermal cells. In the case of stomatal infection the epidermal defences of the host plant are completely turned and infection is a comparatively easy matter, since many fungi possess enzymes which are able to cause disorganization of the cellulose walls of parenchyma cells.

Where, however, the cuticle is perforated, our knowledge of the mechanism employed by the germ tube is very meagre. Busgen (3) has pointed out the importance of appressoria in many cases in bringing the fungus in close contact with the host. Most authors assume, as apparently does Busgen, that the germ tube softens and dissolves the cuticularized epidermal wall in the same way as a cellulose wall. For example, Marshall Ward (11), in his classical paper on a disease of the Lily due to Botrytis, speaks of the germ tube as dissolving its way through the cuticle. Miyoshi $(5$, p. 286$)$ is of opinion that the perforation of many membranes of fungi is due to the secretion of enzymes, although he had been able to show that Botrytis cinerea could perforate a membrane such as gold leaf, upon which it could by no possibility act chemically. Voges (10) speaks of the slime formed by the germ tube of Fusicladium softening the cuticle. Such a view, however, has never been supported by physiological evidence

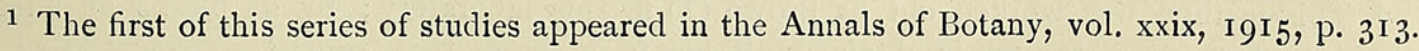

[Annals of Botany, Vo1. XXX. No. CXIX. July, I916.] 
nor by any careful microscopic study of the actual phenomena of penetration. It is certainly improbable, since no enzyme is known which is able to dissolve cuticle.

A study (Brown, 1) in this laboratory of a powerful enzymic extract of the germ tubes of Botrytis cinerea had shown that such an extract was unable to exert any swelling or dissolving action on the tissues of a leaf when placed on the uninjured cuticle, although when injected into the leaf it rapidly brought about disorganization of the tissues. It seemed then advisable to make a careful study of the early stages of infection by Botrytis cinerea, paying particular attention to the phenomena to be observed in connexion with the penetration of the cuticle.

\section{METHODS.}

Cut leaves of the broad bean (Vicia Faba) were used as material for infection. The cultures of Botrytis cinerea used were from the strain employed by Brown (1) in his work. It was found that the spores germinated in water very slowly, or not at all, and very often failed to infect a leaf. For this reason the work has been carried out with spores sown in turnip juice on a leaf; this ensures rapid germination and strong, well-nourished hyphae.

The cultures were grown for ten days at $26^{\circ} \mathrm{C}$. on sterilized potatomush-agar. ${ }^{1} \quad$ The culture, which by this time has produced a plentiful crop of spores, is then flooded with water, and the surface of the medium gently scraped with a scalpel to detach the spores and mycelium. The suspension of spores and hyphae is passed through fine muslin to remove the mycelium, and then centrifuged for a few minutes. The water is then poured off very carefully and sterilized turnip juice is added-Io c.c. of turnip juice to every O.I c.c. of wet spores. The turnip juice is prepared by subjecting peeled and chopped turnips to a temperature of $120^{\circ}$ in the autoclave. for 45 minutes, and subsequently extracting the juice by means of a press. The suspension of spores in turnip juice is used for infection. ${ }^{2}$ Infections were also made with a much less concentrated suspension of spores.

Before infection the leaves are washed with a gentle stream of sterile distilled water to remove as far as possible extraneous spores and dust. They are then placed on damp filter-paper on a sterile Petri dish, and drops of the prepared solution containing spores placed on their upper surfaces.

Material was fixed at intervals mostly in Flemming's fluid (the strong solution diluted with an equal bulk of water), and some in absolute alcohol containing 25 per cent. by volume of glacial acetic acid. It is easy to

1 See Brown (1), p. 68.

2 This method was worked out by Brown (1) in this laboratory; by its means an infecting suspension of standard strength is obtained. It has been shown that the spore concentration may markedly affect the degree of germination. 
gauge roughly the stage of infection as, soon after penetration of the leaf, the tissues in the neighbourhood of the point of entry become brown and then black. The blackening is, of course, a well-known enzymic effect.

In studying later stages of penetration the sections were stained with gentian violet and orange $\mathrm{G}$, or iron-alum-haematoxylin and erythrosin, or Delafield's haematoxylin and eosin (Durand, 4). In the very earliest stages of penetration iron-alum-haematoxylin was used, followed by scharlach red (in equal parts of glycerine and water); such preparations which were mounted in glycerine showed the cuticle stained very sharply. Gentian violet in dilute solution was found useful in demonstrating the stratification of the swollen subcuticular wall; the layering was particularly clear in preparations mounted in 'euparal'.

To demonstrate the outer mucilaginous layers of the walls of the germ tubes and hyphae, fresh material was mounted in 'collargol', a preparation of colloidal silver. The mucilaginous layer then appears as a clear area round the ordinary cell-wall. The mucilaginous coating can also be demonstrated by staining fresh material in dilute watery gentian violet and mounting in water.

\section{OBSERVATIONS.}

Germination. The dry conidia swell when placed in turnip juice and in 2-3 hours show the first signs of a germ tube. In a highly nutrient medium like turnip juice growth is very rapid, and in $\mathrm{I} 5$ hours the germ tube may reach a length of nine spore-diameters. If the germ tubes are growing in drops on a glass plate numerous appressoria will usually be formed in 24 hours, and at the end of 36 hours numerous cross-connexions are to be seen between the hyphae. These connexions and the interweaving of the hyphae convert the originally separate growths into a more or less felted mass.

The germinated spores show numerous nuclei; in the germ tube the nuclei are seen to be arranged in pairs (Pl. X, Figs. 6, 7, 8), and usually show conjugate divisions (Welsford, 12).

Anchorage of the germ tube. It was noticed early in the investigation that young germinated spores, even before any haustoria were developed, usually showed no tendency to become detached from the leaf as a result of the manipulation entailed in fixing, washing in running water, \&c. The cause of the strong adhesion of the young germ tubes to the leaf was found to be the mucilaginous nature of the outer layers of the wall of the germ tube. This appears to have been overlooked by previous workers owing to its transparency ; but it is easily demonstrated by mounting the germinating spores in a fine suspension of dark coloured particles. This method was first employed by Errera (5) to demonstrate the gelatinous sheath round filamentous algae. Instead of the Indian ink used by Errera a preparation 
of colloidal silver, as already stated, was employed. The gelatinous or mucilaginous sheath round the germ tube then shows itself as a clear halo against a brown background (Fig. 5). The sheath is also easily demonstrated by staining with weak gentian violet for thirty seconds and mounting in water.

The mucilaginous envelope cannot be demonstrated in the earliest stages of germination (Pl. X, Figs. I, 2); in such stages the germ tubes do not become fixed to the substratum, such as a glass slip, on which they are growing. Usually it is only when the germ tube has reached a length equal to the spore-diameter that it is able to adhere to the substratum; at this stage a mucilaginous sheath can be demonstrated (Fig. 3). In later stages, eighteen hours after sowing in turnip juice, the mucilaginous sheath is still more obvious (Fig. 4). The mucilage forms a very thin layer round the tip of the germ tube, but at the basal end does not reach quite up to the spore (Figs. 3 and 4 ).

The wall of the young germ tube before the appearance of a mucilaginous sheath appears to be thicker than the inner non-mucilaginous layer of the wall of the older germ tube; this gives support to the view that the swelling is due to the gelatinization of the outer layers.

In fixed and stained preparations the mucilaginous material no longer appears as a continuous sheath, but is reduced to a number of fine granular threads (Figs. 6, 7), which connect the germ tubes and spores to the substratum, and also to one another if the germinating spores occur in close proximity. The threads, as such, are clearly artefacts, and are in all probability mainly the result of the action of dehydrating agents, such as alcohol, on the continuous mucilaginous material.

No mucilaginous sheaths are to be seen in fresh material round the actual spores, whereas in fixed and stained preparations threads are sometimes to be seen connecting not only the germ tubes but also the spores (Fig. 8) to the substratum. The result appears to be simply explained by the more or less general distribution of the mucilage throughout the drop; for such threads are also to be found connecting one germ tube to another and also connecting a germ tube to another spore. In support of this explanation it is to be noted that fluid in which spores are germinating is mucilaginous to the touch.

A thick mucilaginous layer can also be demonstrated round the group of hyphae forming the appressoria which develop so readily on a glass surface (Fig. I3). No doubt such layers are a constant characteristic of appressoria.

Passage of the germ tube through the outer wall of the epidermal cells. The germ tube produced from conidia germinating on the leaf of Bean was never found to pass through the stomata of an uninjured leaf, but always passed through the epidermal cells. It is only after the leaf has 
been infected in this way at other points and the leaf cells have been in part killed, that germ tubes or hyphae pass into the stomata.

The germ tubes produced from spores sown sparsely on a leaf do not usually start penetrating the leaf immediately, but grow for a short time along the surface of the leaf and then turn down and press the point of the tube firmly on the cuticle. The germ tube is usually curved just behind the tip (Figs. 7, I 7). The growing tip has a very tense appearance, being full of protoplasm which stains deeply. It is firmly anchored to the cuticle by mucilaginous material which, as described above, appears in fixed preparations as numerous threads running from the tip to the surface of the leaf (Fig. 6).

The first indication of penetration is a slight indentation of the cuticle and outer epidermal wall which can be observed where the germ tube presses closely upon the cuticle (Figs. 8, I0, I5, and I6). The next step is the actual penetration of the cuticle. The germ tube does not usually break through as a whole, but, if the epidermal wall has not been affected by the presence of neighbouring hyphae, a narrow projection is commonly put out which passes through the cuticle and enters the subcuticular layers of the epidermal wall (Figs. 14, I7, I9). A very close examination was made of these stages, but neither before nor after penetration did the appearance or the staining reactions of the cuticle give any evidence of its being softened or swollen or in any way altered chemically. There thus seems no doubt that the cuticle is ruptured mechanically by the pressure of the tip of the germ tube.

After penetration of the cuticle the intruding germ tube either grows straight on and enters the cavity of an epidermal cell (Fig. 2I), or else it proceeds to grow more or less horizontally beneath the cuticle (Fig. 18). In either case the subcuticular layers of the wall usually soon swell up; but in a few cases, as in Fig. 2I, penetration appears to have occurred without such swelling of the subcuticular layers.

No swelling of the subcuticular cellulose layer was observed before the bassage of the invading hypha through the cuticle. This is in agreement with the results obtained in the third of these studies (Brown, 2) when it was shown that the active extract of $B$. cinerea had no effect on the underlying tissues when placed upon the surface of so sensitive a structure as a rose petal, though its effect was marked directly the continuity of the cuticle was broken.

When once the subcuticular layer of the walls has swollen, hyphae which enter later usually grow horizontally in this layer. Such a direction of growth is no doubt the path of least resistance, and the layer itself doubtless supplies the fungus with suitable nutriment.

It is to be noted that in the cases described above the germ tube enters without the development of any appressorium. Many cases, however, can 
be observed where penetration of the cuticle is delayed to a somewhat later stage. In these cases the tip of the germ tube or hypha swells up and spreads out on the surface of the leaf (Figs. 9, II, I4) and in some cases subsidiary swellings may be produced (Figs. I9, 20). These swellings are, of course, of the nature of simple appressoria. From the swollen hypha where it is closely applied to the leaf a peg-like hyphal outgrowth now appears which pierces the cuticle and pushes its way into the wall of the epidermal cell (Figs. I4, I9). Here also there is no sign of any softening or other chemical action on the cuticle as a careful study of preparations treated with scharlach red shows; there can be no doubt that, as in the case just described, the perforation of the cuticle is due solely to mechanical action, i. e. to the pressure exerted by the peg-like outgrowth. For the exercise of such pressure the hypha from which the outgrowth proceeds must be held firmly to the cuticle; this is achieved by a mucilaginous investment of the apex of the germ tube or of the appressorium. Apart from this adhesion to the cuticle due to the mucilaginous investment, the germ tube is always firmly pressed against the cuticle. Such a pressure is no doubt brought about by an extension in length of the germ tube, which is, at the same time, fixed at its basal end; the basal end, in the case of a young germ tube like that of Figs. 6, 7, may be practically the spore.

Brown (1) in the first of these studies shows that there is no evidence for the secretion by B. cinerea of a special toxic substance other than a cellwall-dissolving enzyme. This is fully borne out by our observations, for in no case were the epidermal cells seen to be adversely affected in any way before the penetration of the cuticle by the germ tubes. We are quite unable to confirm the observations of Nordhausen (7), who described the killing of epidermal cells below the infection drop even when the conidia were only in the very early stages of germination.

Even after penetration of the cuticle has occurred the first obvious change in the epidermal cells is usually the swelling of the walls, while disorganization of the protoplast follows later. It is clear that the hypothesis of a crystalloidal toxin which can diffuse through the uninjured cuticle and kills the cells beneath, as assumed by Nordhausen (7) and Smith (9), is quite untenable. These results are fully supported by Brown's study of the physiological conditions in the 'infection drop' published in the same number of this journal (Brown, 2).

Changes produced after penetration. As already stated, immediately after the cuticle is penetrated and the hyphal ingrowth reaches the subcuticular layer of the wall, this layer begins to swell up. As the swelling gradually increases this layer becomes laminate in structure (Fig. 19). The swelling may be so great that the lumen of the epidermal cell below may be almost completely obliterated. 
The swelling of the cellulose subcuticular layer appears to stretch the cuticle. Possibly this facilitates the entry of other hyphae which find less resistance in the 'thinned out' cuticle, for in the drop infections the number of hyphae entering increases rapidly after the first few have penetrated the cuticle and caused the swelling of the subcuticular layer of the wall. The softening of the cellulose layers which underlie the cuticle

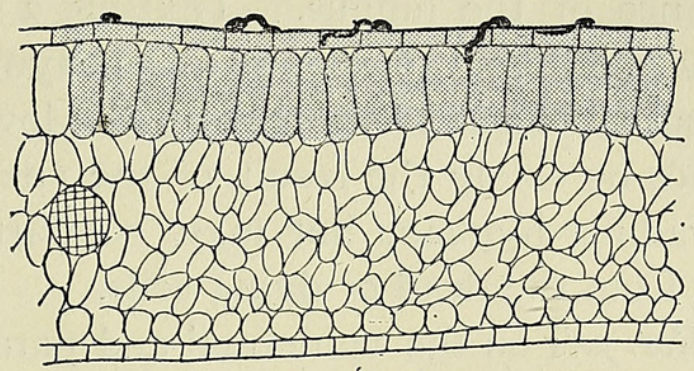

TEXT-FIG. I.

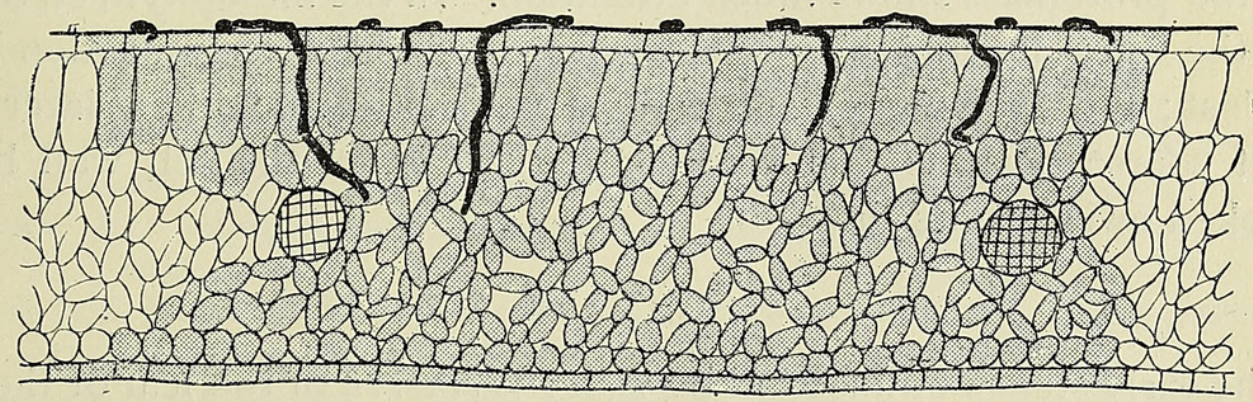

TEXT-Fig. 2.

For explanations see p. 396 .

would also markedly reduce the resistance which that membrane could offer to perforation by mechanical pressure.

When once a number of hyphae have entered the leaf other hyphae are seen to enter through the stomatal apertures, though first infection of the leaf was never observed to be brought about in this way. How far this is due to the filling of the intercellular spaces of the leaf with fluid, either from the liquid on the leaf or by the cell sap exuding from dead cells, is still uncertain.

The question also as to how far the penetration of the leaf is due to chemotropic stimuli arising from slight exudations of substances through the cuticle, or how far it is due to a contact stimulus, still requires further investigation.

As the hyphae penetrate through the epidermis, the cells of the palisade parenchyma become affected. ${ }^{1}$ First, the nuclei move upwards towards the epidermis (Fig. 22), then gradually they begin to disintegrate, the chloroplasts swell, and starch almost disappears from the affected region. The

1 There was no clear evidence of the movement of the nuclei of the epidermal cells towards the outer walls as a response to the development of the fungus on the leaf in the manner described by Ritter (7). The nuclei of the epidermal cells of normal leaves are sometimes found in close proximity to the outer wall. 
dark coloration, which is one of the characteristic signs of death in the bean leaf, gradually spreads through the leaf. Text-fig. I is a diagram of a leaf in which the epidermal cells only are infected, but one hypha has grown down and come in contact with two palisade parenchyma cells. All the palisade parenchyma cells below the infected epidermal area are however discoloured, thus showing that the death of these cells has taken place in advance of the fungus. Text-fig. 2 shows a leaf in which the fungus has penetrated to the spongy parenchyma cells, but the discoloration of the tissues has spread through to the lower epidermis. This discoloration may not be solely the result of the enzyme diffusing out in advance of the invading hyphae, but may be partly due to action of substances liberated from the dead or dying cells.

The action of Botrytis on the epidermal and parenchyma cells respectively is somewhat different. In the epidermal cells the walls usually swell before the protoplast shows much alteration. In the mesophyll, on the contrary, the first morbid change is seen as slight disorganization of the protoplast; the swelling of the wall is not noticeable till a later stage. It is of course possible that changes occur first in the cell wall but are overlooked owing to its thinness.

\section{SUMMARY.}

The early stages of infection by Botrytis cinerea of the leaf of the broad bean (Vicia Faba) have been studied. The spores were grown in drops of turnip juice on the leaf.

When the germ tube produced from a spore has reached a length of about one spore-diameter it can be shown to possess a mucilaginous investment. By means of this sheath it becomes firmly fixed to the substratum.

The germ tube exerts a considerable pressure on the underlying leaf tissues, as is shown by the slight depression of the epidermal wall below it.

Actual penetration of the leaf is usually brought about by the development of a fine peg-like outgrowth from that part of the germ tube which is firmly pressed against the leaf surface.

Penetration can occur without the development of an appressorium.

Prior to the penetration of the cuticle no softening, nor swelling, nor any other change can be observed in the cuticle itself or in the underlying layers of the epidermal wall. The piercing of the cuticle is due solely to the mechanical pressure exerted by the germ tube as a whole or by the special outgrowth from it. Such a method of penetration would clearly be impossible in the absence of the mucilage which holds the germ tube firmly in position and enables it to exert the appropriate pressure.

As soon as the germ tube has forced the cuticular barrier enzyme action can occur, as is shown by the swelling of the subcuticular layers. 
Death of the epidermal cells in advance of the penetration of the cuticle by the germ tube was never found to occur. Even after penetration the walls of the epidermal cells usually swell prior to the disorganization of the protoplast. There is thus no microscopic evidence for the secretion by $B$. cinerea of a special toxic substance other than the cell-wall-dissolving enzyme.

The results of a microscopical study of the early stages of infection of a leaf by the germ tube of Botrytis cinerea are thus in full agreement with the purely physiological observations of Brown (1 and 2).

\section{LITERATURE CITED.}

1. Brown, W. : Studies in the Physiology of Parasitism. I. Action of Botrytis cinerea. Ann. Bot., vol. xxix, I9I5, p. $3^{1} 3$.

2. : Studies in the Physiology of Parasitism. III. On the Relation between the 'Infection Drop' and the underlying Host Tissue. Ann. Bot., vol. xxx, 1916, p. 399.

3. Busgen, M.: Ueber einige Eigenschaften der Keimlinge parasitischer Pilze. Bot. Zeit,, vol. li, 1893, p. 53 .

4. Durand, E. J.: The Differential Staining of Intercellular Mycelium. Phytopathology, vol. i, I9II, P. I29.

5. Errera, L.: Sur l'emploi de l'encre de Chine en microscopie. Bull. de la Soc. Belge de Microscopie, t. x, p. 478 .

6. Mryoshi, M.: Penetration of Membranes by Fungus Hyphae. Jahrb. f. wiss. Bot., vol. xxviii, 189.5, p. 269.

7. Nordhausen, M. : Beiträge zur Biologie parasitärer Pilze. Jahrb. f. wiss. Bot., vol. xxxiii, I899, p. I.

8. Ritter, G. : Traumatotaxis und Chemotaxis des Zellkernes. Zeit. f. Bot., vol. iii, I9I I, p. I.

9. Sмiтh, R. E. : The Parasitism of Botrytis cinerea. Bot. Gaz., vol. xxxiii, 1902, p. 421.

10. Voges, E. : Die Bekämpfung des Fusicladium. Zeit. f. Pflanzenkrank., vol. xx, I910, p. 385.

11. Ward, Marshall : A Lily Disease. Ann. Bot., vol. ii, I888, p. $3 \mathbf{1 9}$.

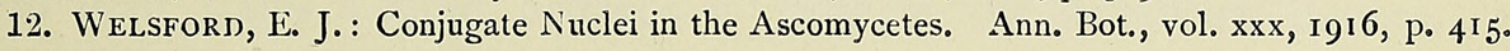

\section{EXPLANATION OF FIGURES IN PLATE X.}

Illustrating Prof. V. H. Blackman and Miss Welsford's paper on Infection by Botrytis cinerea.

The host tissue in every case is that of the leaf of Vicia Faba.

Fig. I. Germinating spore. $\quad \times$ I,200. (Leitz water-immersion objective.)

Fig. 2. Germinating spore. $\times$ I,200. (Leitz water-immersion objective.)

Fig. 3. Germinating spore: older stage showing a slight mucilaginous sheath. $\times$ I,200. Leitz water-immersion objective.)

Fig. 4. Germinating spore: older spore showing thick mucilaginous sheath. $\times$ I,200. (Leitz water-immersion objective.) 
Fig. 5. Germinating spore mounted in a colloidal solution of silver; the mucilage sheath is clearly visible. $\times \mathrm{I}, 200$. (Leitz water-immersion objective.)

Fig. 6. Young germinating spore attached to epidermis of a leaf which has been already infected elsewhere; the epidermal wall has swollen owing to this infection. $\times 1,200$.

Fig. 7. Young germinating spore anchored to the leaf surface. $\times \mathrm{I}, 200$.

Fig. 8. Group of germinating spores; one germ tube is exerting sufficient pressure to push the wall inwards. $\times 1,200$.

Fig. 9. Young germinating spore: the germ tube has begun to spread out on the epidermis to form an appressorium; the wall of the germ tube is slightly altered at the place of contact. $\times \mathbf{I}, 200$.

Fig. I0. Young germinating spore lying on cuticle and pressing it slightly inwards. $\times$ I, 200.

Fig. II. Young hypha swelling out at end to form an appressorium. $\times 1,200$.

Fig. I 2. Appressorium forming at the end of a hypha. The wall at the apex of each branch is slightly modified. $\quad \times \mathrm{I}, 200$. $\times \mathrm{I}, 200$.

Fig. I3. Young appressorium showing mucilaginous sheath. Drawn from fresh material.

Fig. I 4. Young plant of Botrytis with a very small appressorium; the outgrowth has just passed through the cuticle of a previously infected leaf. $\times 1,200$.

Fig. 15. Tip of hypha pressing wall of epidermal cell inwards. $\times 1,200$.

Fig. 16. Ditto. $\times$ I,200.

Fig. I7. Two young Botrytis plants which are surrounded by shrunken remains of dehydrated mucilage. One plant has pushed through the cuticle by a small peg and is spreading out in the subcuticular layer; the second plant is already growing in the swollen wall. $\times \mathbf{I}, 200$.

Fig. 18. A hypha which is growing in the subcuticular layer of the epidermal wall. $, \times \quad \mathbf{1}, 200$.

Fig. I9. A group of appressoria. The pore by which the hypha has entered the subcuticular wall is shown. In this case the wall was specially stained to show the laminate structure of the swollen wall. Other hyphae have already entered the leaf. $\times 1,200$.

Fig. 20. Group of appressoria ; the small pore through which entrance is effected is shown. In this case the hypha has gone straight through the epidermal cell. $\times \mathbf{I}, 200$.

Fig. 2I. A hypha which has penetrated the leaf by means of a small pore; it has continued to grow downwards through the cell, but has caused no swelling of the wall. $\times 1,200$.

Fig. 22. A portion of a transverse section of a leaf. A hypha has penetrated the cuticle and is growing in the outer epidermal wall; the nucleus of the cell has an amorphous appearance. The nuclei of the two cells immediately below have moved upwards in response to a stimulus caused by the intruding hypha. $\times 450$. 
Annals of Botany
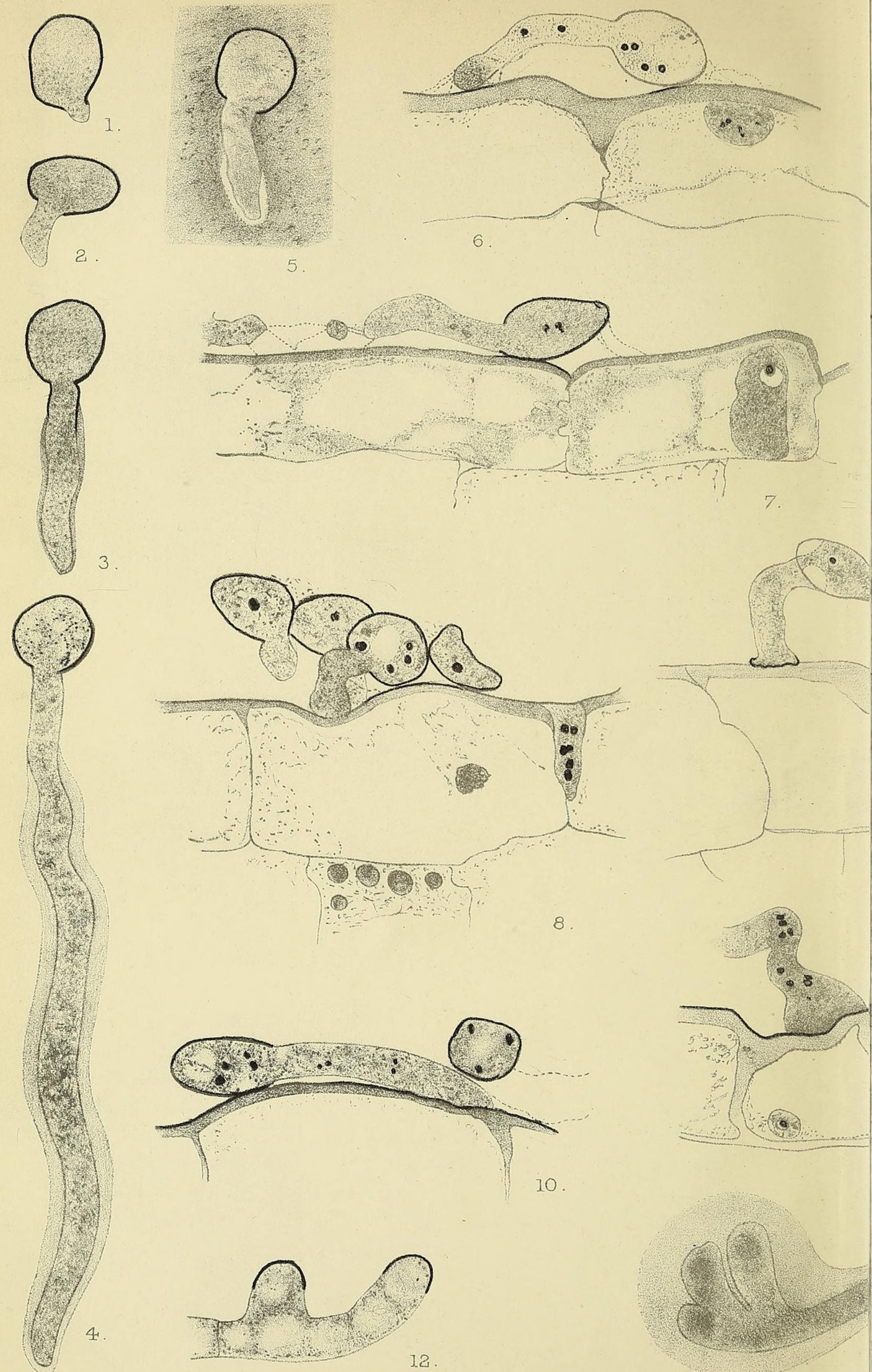

E. J.W. del. 

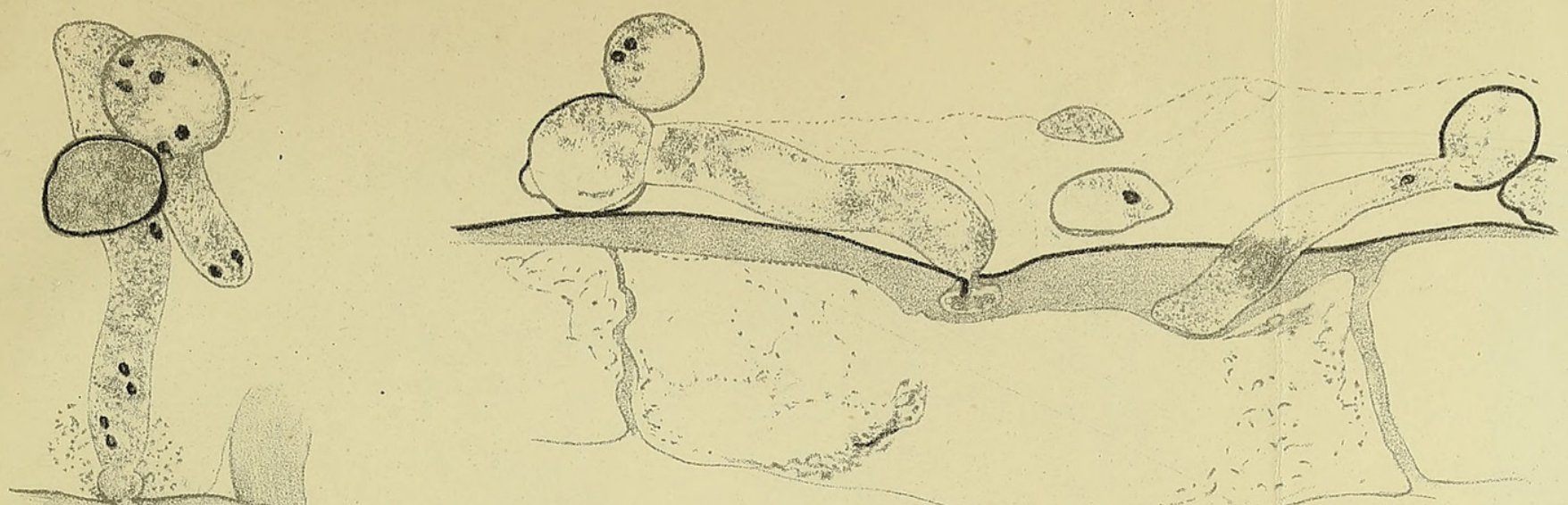

14
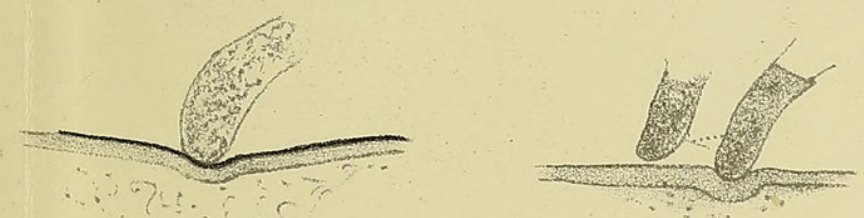

15

16
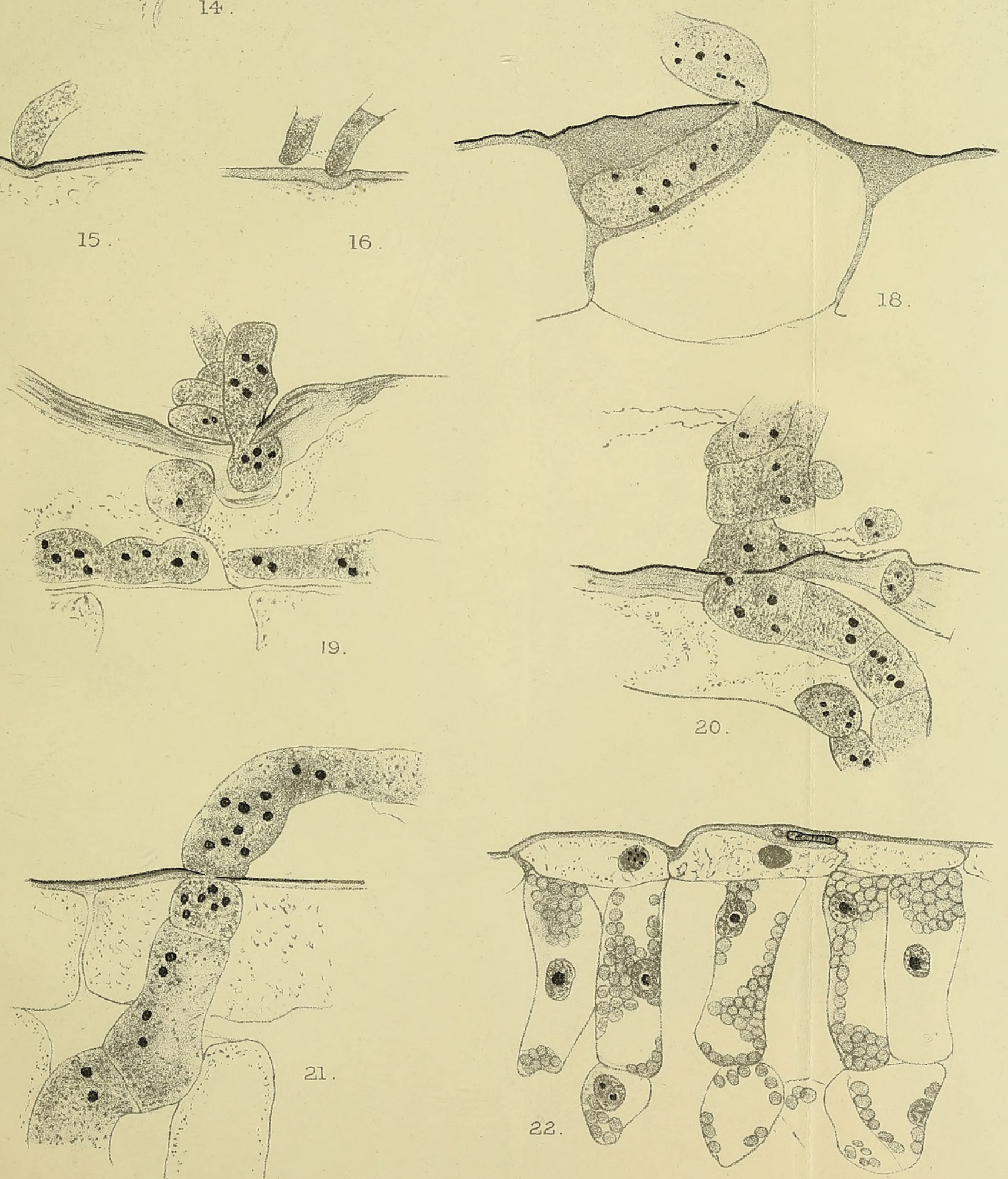
Arnals of Botany
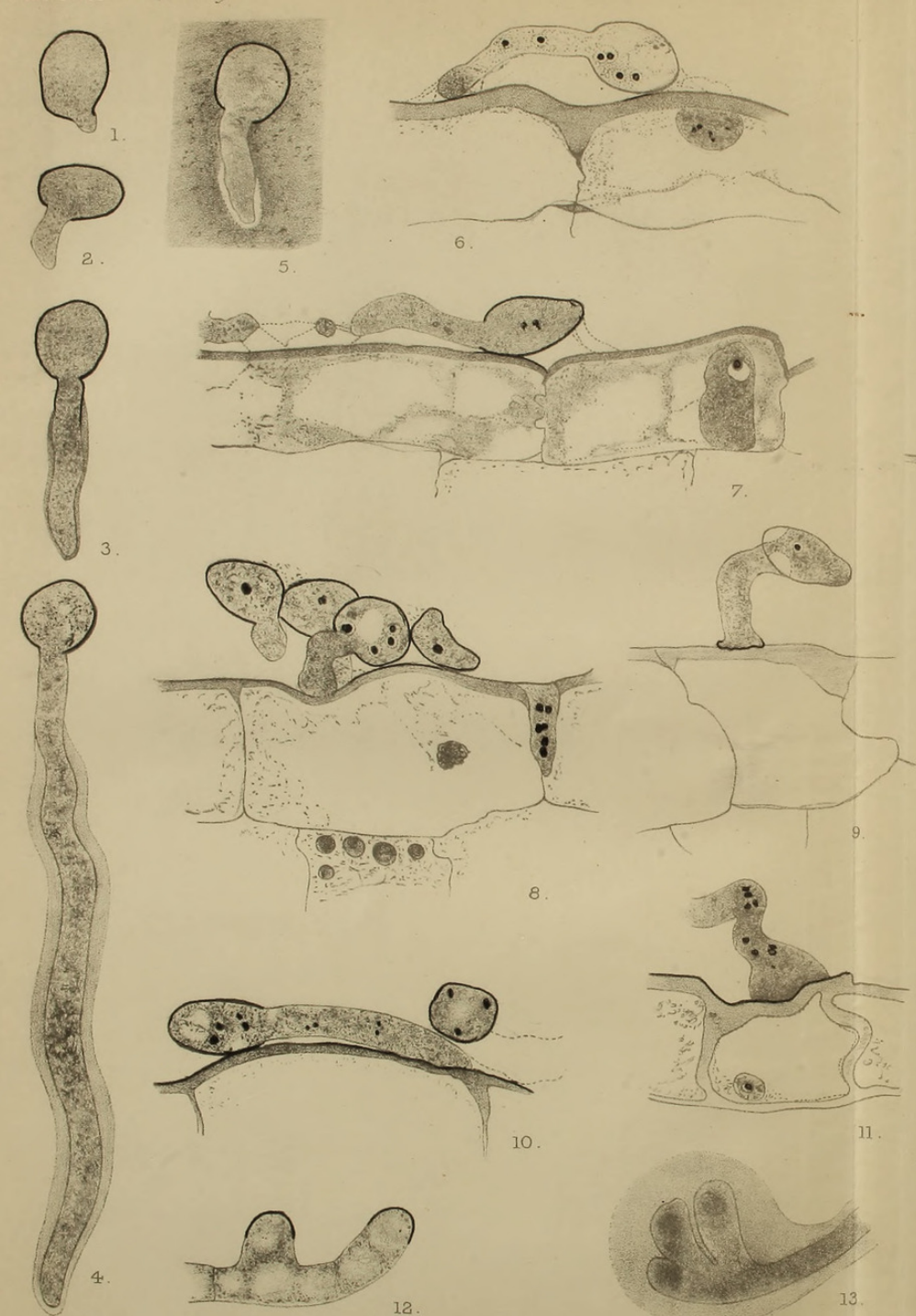
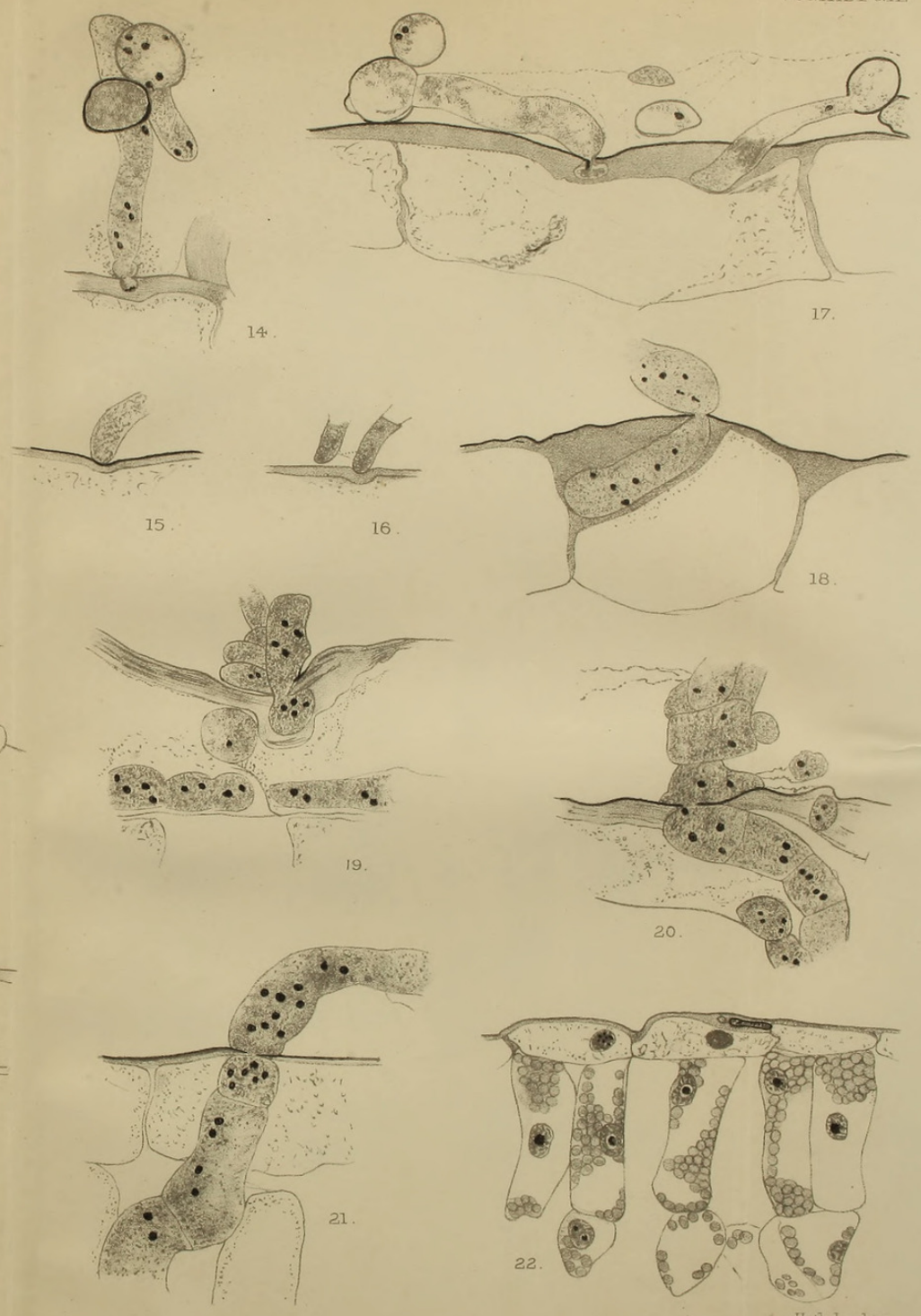


\section{$2 \mathrm{BHL}$ Biodiversity Heritage Library}

Blackman, Vernon H. and Welsford, E. J. 1916. "Studies in the physiology of parasitism. II. Infection by Botrytis cinerea." Annals of botany 30, 389-398. https://doi.org/10.1093/oxfordjournals.aob.a089608.

View This Item Online: https://www.biodiversitylibrary.org/item/237452

DOI: https://doi.org/10.1093/oxfordjournals.aob.a089608

Permalink: https://www.biodiversitylibrary.org/partpdf/320125

\section{Holding Institution}

Smithsonian Libraries

\section{Sponsored by}

Biodiversity Heritage Library

\section{Copyright \& Reuse}

Copyright Status: Not in copyright. The BHL knows of no copyright restrictions on this item.

This document was created from content at the Biodiversity Heritage Library, the world's largest open access digital library for biodiversity literature and archives. Visit BHL at https://www.biodiversitylibrary.org. 